\title{
ECONOMIC EVALUATION OF CEREAL CROPPING SYSTEMS UNDER SEMIARID CONDITIONS: MINIMUM INPUT, ORGANIC AND CONVENTIONAL
}

\author{
Gabriel Pardo ${ }^{1 *}$; Joaquín Aibar²; José Cavero³; Carlos Zaragoza ${ }^{4}$ \\ ${ }^{1}$ EUITA Universidad de Sevilla, Carretera de Utrera, km 1 - 41013 - Sevilla - Spain. \\ ${ }^{2}$ EPSH Universidad de Zaragoza, Ctra de Zaragoza, km 67 - 22071 - Huesca - Spain. \\ ${ }^{3}$ Estación Experimental Aula Dei/CSIC, Apdo. 202 - 50080 - Zaragoza - Spain. \\ ${ }^{4}$ CITA - Dept. de Sanidad Vegetal - Gobierno de Aragón, Aptd.707 - 50080 - Zaragoza - Spain. \\ *Corresponding author <gpardo@us.es>
}

\begin{abstract}
Cropping systems like organic farming, selling products at a higher price and promoting environmental sustainability by reducing fertilizer and pesticides, can be more profitable than conventional systems. An economic evaluation of three cropping systems in a seven year period experiment was performed, using a common rotation (fallow-barley-vetch-durum wheat) in a semi-arid rainfed field of Spain. The minimum input system included mouldboard ploughing, cultivator preparation, sowing and harvest. The conventional system involved mineral fertilizer and herbicide treatments, while the organic system involved composted manure and mechanical weed control. The resulting economic margins were highest with the minimum input system, followed by the organic and conventional systems. If the cereal grain from the minimum input system was sold at a higher price on the organic market, this system was the most profitable. Without the price difference, the organic system was as profitable as the conventional one.

Key words: profitability, organic agriculture, crop rotation

\section{AVALIAÇÃO ECONÔMICADE SISTEMAS DE CULTIVO DE CEREIAS EM CONDIÇÕES SEMIÁRIDAS: CULTIVO MÍNIMO, ORGÂNICO E CONVENCIONAL}

\begin{abstract}
RESUMO: Sistemas de cultivo como agricultura orgânica, cujos produtos têm custo mais alto, mas que promova sustentabilidade ambiental pela redução do uso de fertilizantes e pesticidas, pode ser mais lucrativo do que sistemas convencionais de cultivo. Efetuou-se uma avaliação econômica de três sistemas de cultivo num período experimental de sete anos, utilizando um sistema comum de rotação (pousio-cevada-ervilhaca-trigo duro), sem irrigação, em um local semi-árido da Espanha. O sistema de cultivo mínimo incluía aração com aiveca, preparo com cultivador, semeadura e colheita. O sistema convencional envolvia tratamentos com herbicidas e fertilizantes minerais, enquanto o sistema orgânico envolvia adubação com composto e controle mecânico de ervas invasoras. O sistema com maior retorno econômico foi o de cultivo mínimo, seguido do orgânico e do convencional. O sistema de cultivo mínimo foi o mais lucrativo quando o cereal foi vendido num preço mais alto no mercado orgânico. Sem essa diferença de preços os sistemas apresentaram lucratividades semelhantes.

Palavras-chave: lucratividade, agricultura orgânica, rotação de culturas
\end{abstract}

\section{INTRODUCTION}

The use of mineral fertilizers and herbicides has decreased significantly in semiarid zones to reduce costs and maintain profit margins, which largely depend on subsidies from the European Union. In Spain, the yield of winter cereals in semiarid regions is low (2-3 $\mathrm{t} \mathrm{ha}^{-1}$ ) because yields depend more on the quantity and distribution of rainfall than on agricultural inputs (López-Bellido et al., 1996 and Angás et al., 2006).
Cropping systems like organic farming, selling products at a higher price and promoting environmental sustainability by reducing fertilizer and pesticides, can be more profitable than conventional systems (Delate et al., 2003; Pimentel et al., 2005). Nonetheless, it is reasonable to assume that yield could decrease without chemical fertilization (Pardo et al. 2008; GarcíaMartín et al., 2007), without chemical weeding (Barberi et al., 2000) or with the organic substitutes. By contrast, other researchers indicate that good weed control and also similar yields could be achieved by using 
integrated crops systems in comparison with conventional methods (Swanton et al., 2002). van Herwaarden et al. (1998) sustain that chemical fertilization does not increase yield under a semiarid climate and yields could even diminish.

Evidence in Spain indicates that yields are equal in both conventional and organic rotations (Meco et al., 1998; Lacasta \& Meco, 2006; Agreda \& Abós, 2001). However, most of these authors suggest that the economic profitability of the organic rotation is higher than the conventional system, although they do not perform an economic study per se. Moreover, the majority of these trials do not cover a long year period and then their conclusions are limited.

The aim of this study is to compare the yield and economic outputs of a conventional system with a minimum input and an organic farming system for cereal production over a long term experiment under semiarid conditions. To achieve this objective, a seven year experiment (1997-2003) was performed in a semiarid region of Spain.

\section{MATERIALAND METHODS}

\section{Study area and experimental design}

The trials were carried out from 1997-2003 in a rainfed field located in Sádaba, Zaragoza, Spain $\left(42^{\circ} 17^{\prime} \mathrm{N}, 2^{\circ} 25^{\prime} \mathrm{E}\right)$. The average rainfall over the seven year study period was $197 \pm 105 \mathrm{~mm}$ from sowing to harvest. The texture of the soil was a fine sandyloam, and its main characteristics were: $\mathrm{pH}\left(\mathrm{H}_{2} \mathrm{O}\right) 7.95$, Electric conductivity $0.29 \mathrm{dSm}^{-1}$, Organic matter 26.7 $\mathrm{g} \mathrm{kg}^{-1}$, P (Olsen) $21.9 \mathrm{mg} \mathrm{kg}^{-1}$ and $\mathrm{K}$ (ammonium acetate) $327 \mathrm{mg} \mathrm{kg}^{-1}$. A rotation (fallow-barley-vetch-durum wheat) was established in two contiguous plots (Table 1). Barley cv. Camelot was used in 1997 and 1998, Graphit in 2001, Hispanic in 2002 and Anton durum wheat in 1999, 2000 and 2003. Sowing density was $170 \mathrm{~kg} \mathrm{ha}^{-1}$ (450 seeds $\mathrm{m}^{-2}$ ) for barley, 180 $\mathrm{kg} \mathrm{ha}^{-1}$ (400 seeds $\mathrm{m}^{-2}$ ) for durum wheat and $100 \mathrm{~kg}$ $\mathrm{ha}^{-1}$ (180 seeds $\mathrm{m}^{-2}$ ) for vetch. The row space was $15 \mathrm{~cm}$.

This rotation is a modification of the local practice (cereal-fallow), including a vetch crop (cv. Senda), which is incorporated in the soil as green manure. Both stubble and cereal straw were also incorporated in the soil after the harvest. To replicate the conditions of conventional and organic systems, plots were divided into $90 \mathrm{~m}^{2}$ subplots according to a split-plot design with two factors: fertilization and weeding with three levels per factor. Levels of fertilization applied in each factor are briefly described below:

a) Main factor (fertilization): F1: Control without fertilization; F2: Organic fertilization: $2500 \mathrm{~kg} \mathrm{ha}^{-1}$ of compost made by cereal straw and sheep manure applied at preplant (moisture: $33.3 \%$, organic matter: $57.4 \%$, C: $27.8 \%, \mathrm{~N}: 2.9 \%, \mathrm{P}_{2} \mathrm{O}_{5}: 1.4 \%, \mathrm{~K}_{2} \mathrm{O}: 5.1 \%$ and $\mathrm{Na}$ : 0.89\%), and F3: Mineral fertilization (100 N- $60 \mathrm{P}_{2} \mathrm{O}_{5}-$ $60 \mathrm{~K}_{2} \mathrm{O} \mathrm{kg} \mathrm{ha}{ }^{-1}$, from 1997 to 2000 and $70 \mathrm{~N}-60 \mathrm{P}_{2} \mathrm{O}_{5}^{-}$ $60 \mathrm{~K}_{2} \mathrm{O} \mathrm{kg} \mathrm{ha}{ }^{-1}$ from 2001 to 2003, with the $\mathrm{N}$ applied preplant and at tillering.

b) Secondary factor (weeding): E1: control without weeding; E2: mechanical weeding using a flex-tine harrow (made by Hatzenbichler, St. Andrä, Austria, along the sowing lines during the cereal tillering), and E3: chemical weeding using a herbicide that was chosen depending on the weed types.

The cropping systems analyzed in the experiment were called minimum input (no fertilization and no weeding, F1 and E1), organic (organic fertilization and mechanical weeding, F2 and E2) and conventional (chemical fertilizer and chemical weeding, F3 and E3). Fungicides are not used in the organic system because they are not needed under such semiarid conditions.

\section{Economic analysis}

For the economic part of the analysis, we separately present the operational costs, the incomes and the net margin for the three cropping systems defined by the combination of fertilization and weeding method. The purpose was to facilitate the correct understanding of the relevance of each component on the final farm profitability.

The minimum input system could be considered as organic since it maintains soil fertility by rotating with legumes and burying the stubble and cereal straw (Lacasta \& Meco, 2006). In such case, subsidies could be obtained and the grain could be sold on the organic market. This scenario will be cited as "Minimum (org)" case. By contrast, in the absence of an organic market, the grain from the organic system would have to be sold on the conventional market. We also consider this scenario as "Organic (con)". Therefore, we evaluated the economic results of five alternatives: conventional, minimum input, minimum (org), organic and organic (con).

Table 1 - Crop rotation followed during the trials.

\begin{tabular}{lccccccc}
\hline & $1996-1997$ & $1997-1998$ & $1998-1999$ & $1999-2000$ & 2000-2001 & 2001-2002 & 2002-2003 \\
\hline Plot 1 & Barley $\rightarrow$ & Vetch $\rightarrow$ & Durum wheat $\rightarrow$ & Fallow $\rightarrow$ & Barley $\rightarrow$ & Vetch $\rightarrow$ & Durum wheat \\
Plot 2 & Fallow $\rightarrow$ & Barley $\rightarrow$ & Vetch $\rightarrow$ & Durum wheat $\rightarrow$ & Fallow $\rightarrow$ & Barley $\rightarrow$ & Vetch \\
\hline
\end{tabular}




\section{Costs}

Table 2 shows the operational costs considered for our economic analysis. In order to simplify the data presentation we considered both input and application costs jointly. In the case of the input costs, we used the database in the area when available (MAPA, 1998-2004) and for the application costs, we also calculated the labour costs for some of the machinery operations in each system like harvesting, harrowing etc. (Arnal, 1990; Hernanz et al., 1992; Gil Martínez et al., 1994).

\section{Incomes and margins}

Cereal prices (Table 3) were taken from the Lonja Agropecuaria del Ebro (Ebro Agricultural Market) and the Committee on Ecological Agriculture of Aragon. Yield levels over a five year period (Table 4) are in terms of each management system.The income (Figure 2) of each production system included the value of the grain and subsidies from the European Common Agricultural Policy (CAP) in terms of farmed surface area and organic production.
We also calculated the cereal incomes according to annual subsidies $\left(€ \mathrm{tm}^{-1}\right)$ from the CAP for herbaceous crops and set-aside (MAPA, 1996; Commission Regulation, 1999), according to reference outputs (in tm $\mathrm{ha}^{-1}$ ) provided by the government in the study areas (BOE, 1999) (Table 5).

European regulations provide subsidies for the cultivated surface area and also establish set-aside requirements. The plots in this study were subsidised since there was a rotation with fallow or vetch, as required by the CAP. The percentage of set-aside with respect to the surface area sown is normally $10 \%$ (in our case $0.1 \mathrm{ha}$ ) and is used to calculate the total subsidy per farm (although it can vary slightly per annum).

In 1999, 2000 and 2003 there was an additional payment since the province of Zaragoza was considered as a traditional producer of durum wheat. All CAP subsidies were the same for all systems and years, and somewhat higher for durum wheat (Figure 2, grey bars).

For the specific case of organic productions, the subsidies provided by the Government of Aragón were $21.63 € \mathrm{ha}^{-1}$ in $1997,25.84 € \mathrm{ha}^{-1}$ to $30 € \mathrm{ha}^{-1}$ in 1999

Table 2 - Cost calculated for several agricultural tasks performed during each trial and year.

\begin{tabular}{|c|c|c|c|c|c|c|c|}
\hline \multirow{2}{*}{ Work description } & \multicolumn{7}{|c|}{ Year } \\
\hline & $96-97$ & $97-98$ & $98-99$ & $99-00$ & 00-01 & 01-02 & 02-03 \\
\hline & 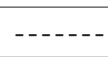 & $-\cdots$ & 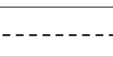 & $€ \mathrm{ha}^{-1}$ & $-\cdots$ & 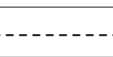 & $-\cdots$ \\
\hline 1 Cultivator tillage & 24.6 & 26.1 & 28.2 & 29.8 & 31.1 & 32.6 & 34.6 \\
\hline 2 Soil bed preparation & 24.6 & 26.1 & 28.2 & 29.8 & 31.1 & 32.6 & 34.6 \\
\hline 3 Sowing of cereal & 60.4 & 63.6 & 69.2 & 70.8 & 68.0 & 69.9 & 76.3 \\
\hline 4 Harvest, straw chopping and storage & 33.3 & 34.5 & 36.0 & 37.8 & 38.6 & 39.9 & 41.5 \\
\hline 5 Burying of stubble & 24.6 & 26.1 & 28.2 & 29.8 & 31.1 & 32.6 & 34.6 \\
\hline 6 Fallow tillage & 51.7 & - & - & 62.0 & 64.5 & - & - \\
\hline 7 Soil bed preparation for vetch & - & 26.1 & 28.2 & - & - & 32.6 & 34.6 \\
\hline 8 Sowing of vetch & - & 56.1 & 58.9 & - & - & 66.9 & 71.8 \\
\hline 9 Chopping vetch & - & 13.7 & 14.4 & - & - & 16.9 & 17.9 \\
\hline 10 Soil incorporation of vetch & - & 54.7 & 58.9 & - & - & 68.3 & 72.1 \\
\hline 11 Organic fertilization & 190.8 & 193.1 & 196.2 & 198.5 & 200.9 & 204.2 & 207.1 \\
\hline 12 Mechanical weeding & 10.1 & 10.7 & 11.6 & 12.2 & 12.7 & 13.4 & 14.1 \\
\hline 13 Preplant mineral fertilization & 78.6 & 80.1 & 82.6 & 83.2 & 83.8 & 84.6 & 85.4 \\
\hline 14 Top dress mineral fertilization at tillering & 30.6 & 42.8 & 43.6 & 44.2 & 30.0 & 30.8 & 31.6 \\
\hline 15 Herbicide application & 25.5 & 23.3 & 32.4 & 33.2 & 61.1 & 47.0 & 55.3 \\
\hline Total cost & 554.8 & 677 & 716.6 & 631.3 & 652.9 & 769.3 & 811.5 \\
\hline
\end{tabular}

Table 3 - Cereal price for conventional and organic markets.

\begin{tabular}{|c|c|c|c|c|c|c|c|}
\hline Market/Year & 1997 & 1998 & 1999 & 2000 & 2001 & 2002 & 2003 \\
\hline & 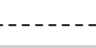 & -1 & 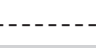 & $€ \mathrm{ha}^{-}$ & 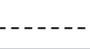 & --- & 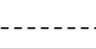 \\
\hline Conventional & 0.138 & 0.138 & 0.150 & 0.144 & 0.126 & 0.126 & 0.156 \\
\hline Organic & 0.210 & 0.210 & 0.228 & 0.240 & 0.210 & 0.180 & 0.192 \\
\hline
\end{tabular}

Crop: barley: 1997, 1998, 2001 and 2002. Durum wheat: 1999, 2000 and 2003 
Table 4 - Yield of winter cereals from 1997 to 2003 in cropping systems.

\begin{tabular}{lcrc}
\hline Year/system & Minimum & Organic & Conventional \\
\hline 1997 (barley) & $2650 \mathrm{a}$ & $2701 \mathrm{a}$ & $2542 \mathrm{a}$ \\
1998 (barley) & $3836 \mathrm{a}$ & $3757 \mathrm{a}$ & $3567 \mathrm{a}$ \\
1999 (durum wheat) & $1222 \mathrm{a}$ & $944 \mathrm{a}$ & $988 \mathrm{a}$ \\
2000 (durum wheat) & $2819 \mathrm{a}$ & $2840 \mathrm{a}$ & $2922 \mathrm{a}$ \\
2001 (barley) & $883 \mathrm{a}$ & $646 \mathrm{a}$ & $789 \mathrm{a}$ \\
2002 (barley) & $1497 \mathrm{a}$ & $1576 \mathrm{a}$ & $1306 \mathrm{a}$ \\
2003 (durum wheat) & $2819 \mathrm{a}$ & $3173 \mathrm{a}$ & $3429 \mathrm{a}$ \\
\hline Average (barley) & 2216 & 2170 & 2051 \\
Average (durum wheat) & 2287 & 2319 & 2446 \\
\hline Average (barley and durum wheat) & 2247 & 2234 & 2220
\end{tabular}

Differences between systems followed by the same letter were not significant, LSD test $(p>0.05)$.

Table 5 - European Common Agricultural Policy (CAP) subsidies in different years in the Sádaba area (Aragon, Spain).

\begin{tabular}{lccc}
\hline Year & Cereal & CAP set-aside & Durum wheat \\
\hline 1997 & 124.87 & 173.85 & - \\
1998 & 135.85 & 172.07 & - \\
1999 & 135.85 & 172.07 & 226.95 \\
2000 & 146.68 & 146.68 & 218.85 \\
2001 & 157.50 & 157.50 & - \\
2002 & 157.50 & 157.50 & - \\
2003 & 157.50 & 157.50 & 206.80 \\
\hline
\end{tabular}

and 2000, and $92.32 € \mathrm{ha}^{-1}$ in 2001, 2002 and 2003 (Villa, 2002). These amounts were also used to calculate the total income of the organic system, although there can be slight variations depending on the government departments (Figure 2, black bars).

Finally, the net margins were calculated as the difference between the total incomes (from crops, subsidies and CAP payments) and costs (for operations, inputs, renting machineries, labour, etc.) of a typical farm. We did not consider repayments for capital, taxes or insurance (Figure 3).

\section{RESULTS AND DISCUSSION}

Yields were similar for the three systems, especially in the first six years (Table 4). The high levels of initial fertility of the soil help to explain why there was no increase in the harvest after adding different fertilizers (i.e., the amount provided was low in relation to the soil conditions). However, as the experiment covers an exceptional long time period, we could also state that the rotation applied was adequate and therefore, fertilization and chemical weed control are not justified from a productive perspective under the trial conditions. Moreover, we obtained similar results in a previ- ous study including 25 analyses in eight locations in Spain with similar climatologically conditions over a four year period under normal soil fertility levels (Pardo, 2003). Of course, under these semiarid conditions, water is always the limiting factor and yields critically depend on the amount of rainfall in spring as stated by Moret et al. (2007) and Díaz-Ambrona \& Mínguez (2001).

Weed density in the controls was variable but generally low (75 \pm 71 annual plants $\mathrm{m}^{-2}$ ) with typical species found in winter cereals (Lolium rigidum, Polygonum aviculare, Anacyclus clavatus, Papaver rhoeas, Fumaria officinalis, Veronica hederifolia). Crops were not affected by diseases over the total trial period.

\section{Economic results}

To facilitate an adequate comparison of the economic results for the three systems, we have differentiated (Figure 1) the more relevant components of the total costs: mineral fertilizer and herbicide (black bars), compost manure and weed control (grey bars) and other operations (white bars). The costs for "other operations" are common for the three systems, and thus we can clearly distinguish the origin of the dif- 


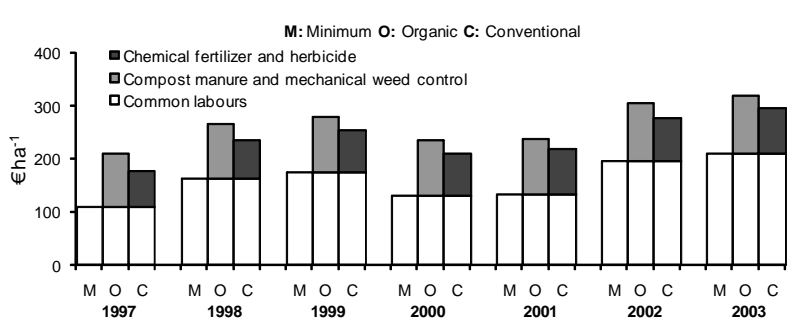

Figure 1 - Farm cost depending on year and agricultural system.

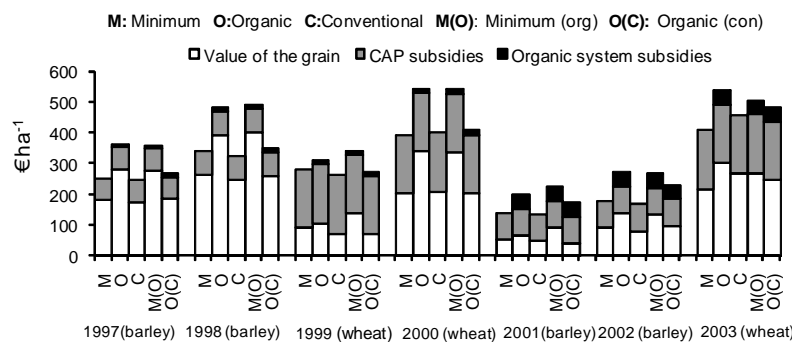

Figure 2 - Total income for a typical farm depending on year and agricultural system. Minimum (org): grain obtained in 'minimum input' system sold on an organic market. Organic (con) grain obtained in 'organic' system sold on a conventional market.

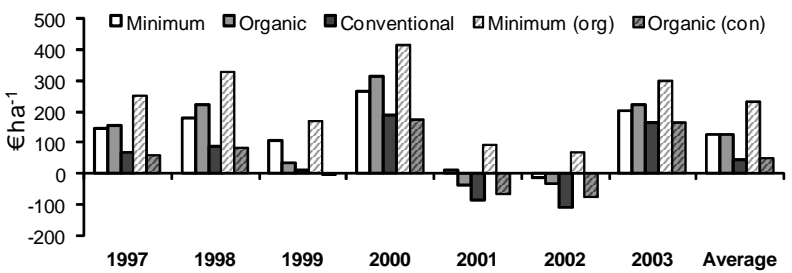

Figure 3 - Annual net margin for a farm depending on the agricultural system. Minimum (org): grain obtained in 'minimum input' system sold in an organic market. Organic (con): grain obtained in 'organic' system sold in a conventional market.

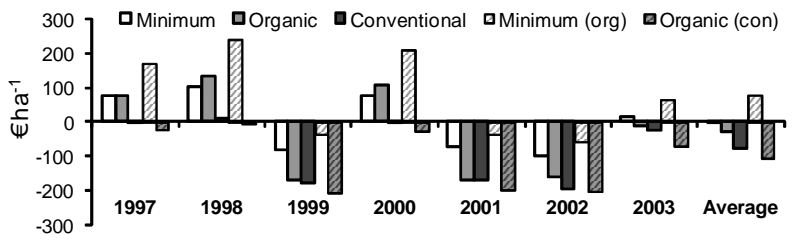

Figure 4 - Annual net margin for a farm depending on the agricultural system without subsidies. Minimum (org): grain obtained in 'minimum input' system sold in an organic market. Organic (con): grain obtained in 'organic' system sold in a conventional market.

ferences between systems. Costs were lower by using the minimum input system (not fertilization or weeding), and higher with the organic system in comparison to the conventional one (Figure 1). This result confirms the findings by Pimentel et al. (2005), who obtained an increase of $25-30 \%$ of costs in the organic system with respect to the conventional farming.
The compost was more expensive $\left(0.06 € \mathrm{~kg}^{-1}\right)$ and more difficult to apply than the mineral fertilizer due to the type and dimension of the manure distributor needed for the application (slower than the mineral one). Moreover, mechanical weed control was cheaper than herbicide application (Table 2). The cost of herbicide application (Table 2) depends on the active ingredient applied every year in the farm, which was related to the type and amount of weeds found in each specific year. In the same way, the farm costs were less in 96-97, 99-00 and 00-01 than in 97-98, 98-99, 01-02 and 02-03 since the costs from neighbouring crops were lower in fallow than in vetch to bury.

Given that the yields were similar for the three systems, the value of the organic grain was higher because of its higher market price. Conversely, the income results for the minimum and conventional systems were similar (Figure 2). Therefore, since crop yield was similar, differences in margins were determined by differences in labour costs and market prices. Lower input costs in the minimum system were compensated by a higher sale price in the organic system. The economic margin of the organic option (266\%) was similar to the minimum system (271\%) and more than double of the conventional system (100\%) (Figure 3). Meco et al. (1998), Lacasta \& Meco (2006), (Agreda \& Abós, 2001) emphasize that organic cropping systems are more profitable than conventional systems even without considering the higher market prices for organic products. Delate et al. (2003) obtained an increase of 25\% in economic results for an organic system in relation to conventional agriculture with more profitable crops (cornoat-alfalfa) and more favourable climate conditions.

Assuming a higher market price, the margins of the minimum input system (minimum (org), Figure 3) improve substantially (496\%), almost five times higher than the conventional option. On the other hand, if the organic cereal is sold at the conventional price (organic (con), Figure 3), it is just as profitable (103\%). In such a case, if specific subsidies for organic agriculture are not considered, an organic system would be the worst option because the costs of organic fertilization and weeding (application of the compost and flex tine harrowing) are not compensated by yield increase.

Without subsidies, the minimum option would have been the most profitable if sold at organic price in four of the seven years of study (Figure 4). These results confirm that conventional and organic agriculture are unfeasible without subsidies, even if the organic grain can be sold at a higher price. These results are important if we consider that the trend from the last reform in 2003 is to cut subsidies in the scope of the CAP and the promotion of sustainable agriculture in semi-arid areas in Spain. 
The organic system generates good economic results in years 1997, 1998, 2000 and 2003, but in average terms, the profitability of the organic system is similar to the minimum for the total period, even when considering the higher market price for organic crops (Figure 3). The reason is that the margin of the organic systems critically depends on the yield obtained and also on the high market prices. Thus, in the long term, the use of compost and mechanical weed control are not justified from the productive (Table 4) or economic points of view. It may be reliable in the case that the minimum system is not considered organic and compost had to be applied.

According to the average cereal price during the seven years of the study and the costs of each system, we would need 2,277 $\mathrm{kg} \mathrm{ha}^{-1}$ of cereal to pay for the costs of minimum system, 2,517 kg ha' ${ }^{-1}$ for the cost of the organic system, and 3,409 $\mathrm{kg} \mathrm{ha}^{-1}$ for the costs of the conventional system. None of these values was obtained, especially for the conventional option (Table 4).

Current agricultural practices in semiarid areas are similar to a minimum system since farmers have substantially decreased the use of fertilizers and herbicides. Usually nitrogen fertilizers are applied at tillering if the water content in the soil during winter is adequate, while herbicides are not applied if there are no special problems. These farming practices and the results of our study suggest that minimum production can be easily adopted since yield can be maintained using the crop rotation proposed. Furthermore, the minimum system can legally obtain the subsidies for organic farming and also contributes to diminish the environmental impacts of agriculture because it reduces the petroleum dependence. In this sense, the current study has to be completed by a further analysis on the environmental effects of the three systems. As pointed out by Laurent et al. (2003) and Pardo et al. (2008), the correct evaluation of the agricultural activities should consider the economic, social and environmental aspects.

\section{REFERENCES}

AGREDA, J.; ABÓS, J. Rentabilidad de los cultivos ecológicos. Navarra Agraria, v.126, p.32-38, 2001.

ANGÁS, P.; LAMPURLANÉS, J.; CANTERO-MARTÍNEZ, C. Tillage and $\mathrm{N}$ fertilization effects on $\mathrm{N}$ dynamics and barley yield under semiarid Mediterranean conditions. Soil and Tillage Research, v.87, p.59-71, 2006.

ARNAL, P. Análisis económico de distintos sistemas de laboreo. El campo, v.117, p.64-66, 1990.

BARBERI, P.; SILVESTRI, N.; PERUZZI, A.; RAFFAELL, M. Finger-harrowing of durum wheat under different tillage systems. Biological Agriculture and Horticulture, v.17, p.285-303, 2000.
BOLETIN OFICIAL DEL ESTADO-BOE. Real Decreto 1983/ 1999 sobre pagos por superficies a determinados productos agrícolas. $\mathrm{n}^{\circ}$ 296, 10 dic. 1999.

DELATE, K.M.; DUFFY, M.; CHASE, C.; HOLSTE, A.; FRIEDRICH, H.; WANTATE, N. An economic comparison of organic and conventional grain crops in a long-term agroecological (research LTAR) site in Iowa. American Journal of Alternative Agriculture, v.18, p.59-69, 2003.

DÍAZ-AMBRONA, C.H.; MÍNGUEZ, M.I. Cereal-legume rotations in a Mediterranean environment: biomass and yield production. Field Crops Research, v.70, p.139-151, 2001.

COMMISSION REGULATION. Por el que se establece un régimen de apoyo a los productos de determinados cultivos herbáceos EC Regulation (EC) $\mathrm{n}^{\circ}$ 1251, 17 mayo 1999.

GARCÍA-MARTÍN, A.; LÓPEZ-BELLIDO, R.J.; COLETO, J.M. Fertilisation and weed control effects on yield and weeds in durum wheat grown under rain-fed conditions in a Mediterranean climate. Weed Research, v.47, p.140-148, 2007.

GIL MARTINEZ, M.; VELILLA, G.; RUIZ, A.. Datos sobre tiempos de trabajo en agricultura: referencias bibliográficas; Dirección General de Tecnología Agraria. Diputación General de Aragón. Información Técnica, 1/94, 1994. 12p.

HERNANZ, J.L.; SANCHEZ GIRON, V.; CERISOLA, C.; NAVARRETE, L.; FERNÁNDEZ-QUINTANILLA, C. Análisis de la energía consumida y de los costes de producción de tres sistemas de laboreo ensayados en tres cultivos extensivos. Anuario INIA, v.7, p.209-225, 1992.

LACASTA, C.; MECO, R. Agricultura ecológica: una alternativa económica y energética para los agrosistemas de cereal en el secano español. Tierras de Castilla León, v.128, p.86-99, 2006.

LAURENT, C.; MAXIME, F.; MAZE, A.; TICHIT, M. Multifonctionnalité de l'agriculture et modèles de l'exploitation agricole. Economie Rurale, v.273-274, p.134-152, 2003.

LÓPEZ-BELLIDO, L.; LOPEZ-GARRIDO, F.J.; FUENTES, M., CASTILLO, J.E.; FERNÁNDEZ, E.J. Long-term tillage, crop rotation, and nitrogen fertilizer: effects on wheat yield under rainfed Mediterranean conditions. Agronomy Journal, v.88, p.783-791, 1996.

MECO, R.; LACASTA, C.; ESTALRICH, E.; GARCIA MURIEDAS, G. La agricultura ecológica en cereales, una alternativa para zonas semiáridas. In: CONGRESO DE LA SOCIEDAD ESPAÑOLA DE AGRICULTURA ECOLOGICA, 3., Valencia, 1998. Proceedings. Valencia: Sociedad Española de Agricultura Ecológica, 1998. p.83-93.

MINISTERIO DE AGRICULTURA PESCA Y ALIMENTACIÓN MAPA. La política agraria común en España: campaña 96/ 97. Madrid, 1996.

MINISTERIO DE AGRICULTURA PESCA Y ALIMENTACIÓN MAPA. Análisis de la economía de los sistemas de producción: resultados técnico-económicos de explotaciones agrícolas de Aragón en 1997-2004. Madrid: Subsecretaria de Agricultura, Pesca y Alimentación, 1998-2004.

MORET, D.; ARRÚE, J.L.; LÓPEZ, M.V.; GRACIA, R. Winter barley performance under different cropping and tillage systems in semiarid Aragón (NE Spain). European Journal of Agronomy, v.26, p.54-63, 2007.

PARDO, G. Estudio comparativo de la fertilización y el desherbado en el cultivo ecológico de cereales en zonas semiáridas. Pamplona: Universidad Pública de Navarra, 2003. 206p. Thesis (Ph.D.).

PARDO, G.; RIRAVOLOLONA, M.J.; PETIT M.S.; FARCY, P.; MUNIER-JOLAIN N. Consecuencias del manejo integrado de malas hierbas sobre la organización del trabajo y la rentabilidad económica de la explotación agrícola. ITEA, v.104, p.448-471, 2008.

PIMENTEL, D.; HEPPERLY, P.; HANSON, J.; DOUDS, D.; SEIDEL, R. Environmental, energetic, and economic comparisons of organic and conventional farming systems. BioScience, v.7, p.573-782, 2005. 
RODRÍGUEZ PEREZ, M.; DIAZ-SALAZAR, J. Principales incidencias malherbológicas en la provincia de Ciudad Real:. campaña 2000-2001. In: REUNIÓN DEL GRUPO DE TRABAJO MALAS HIERBAS Y HERBICIDAS, 21., Ciudad Real, 2002. Proceedings. Ciudad Real: Junta de Castilla la Mancha, 2002. 5p.

SWANTON, C.J.; SHRESTHA, A.; CLEMENTS, D.R.; BOOTH, B.D.; CHANDLER, K. Evaluation of alternative weed management systems in a modified no-tillage corn-soybeanwinter wheat rotation: weed densities, crop yield, and economics. Weed Science, v.50, p.504-511, 2002.

van HERWAARDEN, A.F.; FARGUHAR, G.D.; ANGUS, J.F., RICHARDS, R.A.; HOWE, G.N. "Haying-off" the negative grain yield response of dryland wheat to nitrogen fertiliser. I. Biomass, grain yield, and water use. Australian Journal of Agricultural Research, v.49, p.1067-1081, 1998.
VILLA, F. La Agricultura Ecológica en Aragón. Evolución de la situación actual y organización. Plan de experimentación y divulgación hacia el sector. In: JORNADAS DE AIDA. PRODUCCIÓN SOSTENIBLE EN EL MEDIO AGRARIO, 34., Zaragoza, 2002. Proceedings. Zaragoza: Asociación Interprofesional para el Desarrollo Agrario, 2002. p.22-31.

Received April 28, 2008

Accepted April 15, 2009 